\title{
Investment in Hydropower Sector: Opportunities and Risks
}

\author{
Ratna Sansar Shrestha
}

$\mathbf{I}$ t is remarkable that, during past one decade, domestic investors have invested US $\$ 75.5$ million and foreign investors $\$ 233.6$ million in the electricity generation business in Nepal. Similarly, $\$ 13.5$ million was invested in buying shares in Butwal Power Company held by the Government of Nepal. Thus, in a span of one decade, the private sector has succeeded in mobilizing \$322.6 million into the power sector. The details of the investment are as follows:

\begin{tabular}{|c|c|c|c|}
\hline \multirow{2}{*}{ Project } & \multirow{2}{*}{$\begin{array}{c}\text { Capacity } \\
\text { in MW }\end{array}$} & \multicolumn{2}{|c|}{ Investment MUSD'1 } \\
\hline & & Local & International \\
\hline Khimti & 60 & 5.1 & 134.9 \\
\hline Bhotekoshi² & 36 & 2.5 & 97.5 \\
\hline Syange & 0.183 & 0.3 & \\
\hline Indrawati & 7.5 & 22.1 & 1.2 \\
\hline Chilime & 20 & 32.9 & \\
\hline Piluwa & 3 & 4.4 & \\
\hline Chaku & 1.5 & 2.1 & \\
\hline Sunkoshi & 2.6 & 5.3 & \\
\hline Rairang & 0.5 & 1.0 & \\
\hline Total & 131.3 & 75.8 & 233.6 \\
\hline
\end{tabular}

Table 1. Status of private investment in hydropower sectors investment opportunity. In other words, the scope for investment in hydropower in Nepal is limitless. In this respect, it needs to be remembered that ramification of investment in hydropower sector is equity investment by the entrepreneurs with complementary debt financing ${ }^{4}$ from financial intermediaries (FIs). It is not possible for an entrepreneur to implement a hydropower project just by making an equity investment. From this perspective, implementation of a hydropower project also depends on an entrepreneur's ability to mobilize debt funding. However, there are some major constraints in mobilizing funding from FIs for investment in a hydropower project, which are detailed below.

\section{Market failure and portfolio mismatch in Fls}

At present, Nepal is facing a market failure condition in its economy, high liquidity in the system leading to very low interest rates on deposits offered by FIs, while very few of them have experience with, or appetite for, long-term infrastructure projects, which are invariably capital-intensive. Projects needing long-term financing have been facing problems in securing finances. There are seven national level development banks mandated for long-term financing while a number of commercial banks are also financing long-term projects to an extent. However, the terms of the debt offered by these banks and their capital base are limited.

The market failure condition described

\section{Opportunities}

According to National Planning Commission, at the end of 9th Five Year Plan, $40 \%$ of the population in Nepal had access to electricity. ${ }^{3}$ This means that $60 \%$ of the population still has no access to electricity, indicating that there is a solid market for electricity in Nepal. Further, it also needs no reminding that most of those who have access to electricity are facing severe load-shedding and the magnitude of which is likely to increase further in the near future. All this confirms that an abundant market for electricity exists within Nepal. If one is to include the potential export market of electricity to India then the size of the market increases by a magnitude.

The tremendous market for electricity manifests above is due to the fact that their deposit base is of a short-term nature and it will be a portfolio mismatch for them to offer long-term loans. This condition is inhibiting FIs from assisting private developers in participating in the power sector development in the requisite way.

\section{Lack of 'project finance' instrument}

Project finance is specific mode of financing used by FIs under which the very project for which finance is being sought is accepted by FIs as collateral and no additional or external collateral is required for the purpose, thereby resulting in limited recourse to the institutions providing debt financing. This is also called non-recourse financing. In this kind of 
financing, the proponent does not need to lodge other tangible or intangible assets as collateral. However, FIs in Nepal do not 'like' project finance, and, therefore, a proponent is required to put a tangible or intangible assets of value higher than the debt amount to include a margin as collateral, or to furnish corporate or personal guarantee or third party guarantee or parent company guarantee, and so forth. Throughout the world, investors have not been financing front loaded projects, like hydropower, fully with their equity (even if they were capable), nor would it be prudent for them to be exposed to the assortments of risks just on their own. Project finance is a mechanism for sharing the exposure to such risks in the proportion of debt equity ratio. In order to encourage developers to participate in the power sector, FIs need to make available funding on 'project finance' basis.

\section{Lack of 'due diligence' capability in Fls}

Financing hydropower can not be compared to any other financing. In order for an FI to lend for hydropower projects, it will have to be able to understand the project intimately. Uniquely, the hydropower sector uses a number of disciplines, like civil, electric, and mechanical engineering, hydrology, geology, etc. Without contribution from each of these disciplines, it will not be possible to form an opinion about a project and to determine whether it is bankable or not. However, no FI in Nepal possesses this kind of expertise in house. Because of this constraint, banks have shown hesitation to invest in the power sector.

Another facet of the same problem is that FIs do not like the project finance instrument simply because they do not have the necessary 'due diligence' capability.

\section{Central bank guidelines insensitive to power sector}

Nepal Rastra Bank (NRB), the nation's central bank, has certain rules regarding provisioning in its guidelines to banks in Nepal. The NRB requires banks to make a $1 \%$ provision for 'good' loans; i.e., loans that are overdue by less than three month. Loans overdue by three to six months are called 'substandard' loans, and the provisioning requirement for such loans is $25 \%$. Loans overdue by six month to a year are termed 'doubtful', and $50 \%$ is required to be provisioned for such loans. The provisioning requirement for loans overdue by more than one year is $100 \%$.

In the power sector, the time overrun by one year is held to be normal (the Middle Marsyangdi Project was scheduled to be commissioned in 2004, but it is still under construction!). If banks started making
$100 \%$ provision for their investments in the hydropower sector, they would becomeinsolvent and would also adversely impact the power sector as well as the economy of the country.

\section{Power development fund}

In order to finance local Independent Power Producer (IPPs), the Government of Nepal established the Power Development Fund (PDF) with the support of the World Bank. With a start-up capital of US\$35 million, the PDF intends to finance $60 \%$ of the cost of projects up to $10 \mathrm{MW}$ and $40 \%$ of the cost of projects above $10 \mathrm{MW}$. The fund is administered by the Nepal Bangladesh Bank Limited, a private commercial bank in Nepal.

The PDF has yet to finance any project because the criteria for qualifying for PDF financing are too rigid for compliance by small IPPs. The criteria require prior clearance from the environment department to qualify for a loan. This usually takes more than two years. Developers cannot wait for such a long period. The resettlement issues are too stringent and are more relevant to large projects than to small projects. The proposal screening criteria are as per the international development agency guidelines, which is very time-consuming. The threestage due diligence process of the PDF itself takes over 180 days. The purpose of establishing the PDF to help finance local IPPs has thus not been met due to the preconditions set down by the PDF. Recently, adding to the complications, the administrator (i.e., the bank appointed to administer the PDF) has been taken over by the NRB after declaring it troubled.

\section{Risks}

Financing a hydropower project is very heavily dependent on the prudent management of various types of risks. This involves identification of various risks associated with a project and assessment thereof. However, the most important step lies in arranging measures to mitigate such risks including an effective insurance program. Let us take a look at certain important risks from the perspective mentioned here.

\section{Foreign exchange risk}

A developer can borrow locally or from foreign institutions and the conditions with regard to security will be same. However, the borrower's exposure to certain risk will be different if the source of debt is overseas. There are mainly two types of risks that a borrower needs to be aware of while borrowing from a foreign lender.

A foreign exchange risk is inherent in foreign loans due to the fact that foreign currency tends to be relatively strong compared to Nepalese currency. This 
risk materializes with the devaluation if revenue is denominated in local currency while having to service the loan denominated in foreign currency. Similarly, this risk also does manifest in rising cost of imports. This risks can be mitigated by either (a) having the loan denominated in local currency, or (b) rate of revenue denominated in foreign currency. In the case of increase in the cost of imports an insurance coverage against cost escalation would mitigate this risk.

\section{Repatriation risk}

Another risk associated with foreign loan is 'repatriation risk'. This becomes of greater concern to a lender if it is not able to repatriate the proceeds of debt servicing. Generally, governments of development countries, in their quest to attract foreign investment, have enacted legislation guaranteeing repatriation. If such a guarantee is not available, either the lender will not make a loan or will make it subject to exorbitant rate of interest. In Nepal repatriation is guaranteed by the Foreign Investment and Technology Transfer Act of 1992 and the Electricity Act of 1992 for hydropower projects. A foreign equity investor is also subject to this risk.

\section{Sovereign risk (country risk)}

A foreign entrepreneur investing in Nepal is exposed to risk such as those associated with the government's credit worthiness, the possibility of confiscation, expropriation and nationalization (CEN Risk), changes in the local political environment and enforceability of contracts. These types of risk are known as sovereign and country risk. The Multilateral Investment Guarantee Association (MIGA), a member of the World Bank group, ensures against such risk for a fee. However, the availability of such insurance is limited only to foreign investors.

\section{Interest rate risk}

It is now time we also touched upon the concept of interest rate risk. Lenders offer two kind of interest: (a) floating rate and (b) fixed rate. Floating rate entails changes in the interest rate during the term of the loan, thereby introducing an element of uncertainty or risk for the borrower. Banks prefer floating rate as they need to be able to adapt to changes in financial market as well as cover their own exposure to the vagaries of changing interest rates (including bank rates). For a developer, fixed rate is the best way to mitigate this risk. However, banks tend to add a margin to the then prevalent rate to cushion their own risk.

\section{Inflation rate}

The real value of a unit of nominal currency tends to depreciate over time with inflation. Even hard currency is subject to this risk. Escalation in the rate of tariff is the only answer, short of trying to hold down the inflation with one's bare hands!

\section{Legislative change risk}

Here we are talking about the risk of changes in the country's laws that (a) increase rates and taxes or other expenses and liabilities, (b) reduce project revenues, or (c) reduce the value of the assets. Such changes adversely impact the viability of a project. Generally, an entrepreneur has to take such risk. However, it can also be mitigated by passing the impact through to the utility provided that the utility is amenable to such a pass through.

\section{Market risk}

It is common knowledge amongst engineers that energy requires a guaranteed market due to the constraints with regard, primarily, to storage and transmission. A simple way to mitigate this risk is to sign a long term Power Purchase Agreement (PPA) with the utility.

\section{Revenue risk}

A developer can have a long term PPA, but such a PPA may not ensure plant factor at a specific level if the utility accepts delivery of the energy at its pleasure, mainly in the case of a run-of-the-river type project lacking poundage. This means there will not be a guaranteed stream of revenue to the project in order for it to meet its financial obligations with regard to (a) operation, maintenance and repairs, and (b) debt servicing. A 'take or pay' type of PPA mitigates this risk.

However, with respect to both market risks and revenuerisk, it needs to be noted that electric energy is already being traded in spot markets in Western Europe.

\section{Payment risk}

This risk emanates from the lack of creditworthiness on the part of the utility, the buyer of the energy. In many developing countries, stateowned utilities do not have established credit histories and also suffer from records of poor management, over-employment, high leakage (technical or otherwise), etc.

Developers are known to ask the government to issue a counter guarantee to cover the payment risk. This basically entails a government standing surety to the fact that the utility pays its dues to the developer in time, and in the case of a utility's failure to meet its obligations the government is required to promptly make payment to mitigate the delinquency of the utility. Now-a-days multilateral funding 
agencies like The World Bank take a dim view of a government issuing a counter guarantee. Having a letter of credit put in place by the utility with the IPP as the beneficiary is another way of mitigating this risk over the short term.

\section{Construction risks}

Time and cost overrun risks are one group of construction risks. Time overrun risk results in loss of revenue and may also raise the cost due to inflation. It also raises the total amount of interest during construction of the debt financing and may even attract penalties for late delivery of energy. Other construction risks are force majeure risk, socioeconomic/ environmental risk, geological risk, performance risk, design risk, etc. One can arrange insurance coverage against such risk like CAR, TAR, EAR, professional liability, etc., including 'advance loss of profit insurance' that can be complemented by signing a 'fixed price' turnkey contract (or EPC contract) and incorporating a clause for imposition of liquidated damages on the contractor for delayed substantial completion or commissioning of the plant.

\section{Hydrological risk}

The 'take or pay' nature of the PPA guarantees that all energy produced by a plant, depending on the availability of water, irrespective of whether the season is dry or wet, shall be turned into cash. However, if there is no water to generate energy due to the change in the level of precipitation, climatic reason or change in the hydrology of the catchments area, then these projects are on there own. This risk emanates from the fact that seasonal rainfall patterns affect the amount of water available to a hydropower plant and generation may fall below contract levels in any season, thus threatening the revenue stream of such projects. Obviously, a dry year will be an unmitigated disaster for a hydropower plant. The most effective way to mitigate hydrology risk is to gather hydrological data for reasonable number of years in the past and design the project accordingly, after having selected a project with better hydrological potential as well as information.

\section{Conclusion}

There is no need to be frightened by the list of risks dealt with above, as most of the risk can be mitigated in some way or other. There is an old saying: 'no risks, no gain'. The entrepreneurship lies in taking risk and also being able to manage it. If an investor is able to do so then there is ample opportunity to invest in hydropower sector in Nepal. However, necessary measures must be undertaken to mitigate the constraints in financing power sector, described above.

Ratna Sansar Shrestha, FCA is a management professional specializing in financial/ economic, legal and managerial aspects of hydropower projects, renewable energy technologies, environmental enterprises, carbon trading, etc. He is also a Fellow of the Institute of Chartered Accountants of Nepal and a corporatelawyer accredited to the Nepal Bar Council. Currently he is a member of board of directors of Everest Bank Ltd. as well as Butwal Power Company Ltd. He also worked as a member of board of directors of Nepal Electricity Authority from December 2002 till August 2004. He is also attached to Kathmandu University School of Engineering as a visiting faculty in its Master of Engineering program.

\section{End notes}

1. As these are ballpark numbers converted into US Dollars from Nepalese currency, there may be minor differences.

2. One of the main foreign equity investors in the Bhotekoshi Project has already sold its shares to an investor in Nepal.

3. The breakdown of this $40 \%$ has been given as: $33 \%$ covered by Nepal Electricity Authority, 2\% covered by alternative modes of electrification, and $5 \%$ electrified in unexplained way(s). But according to the data published by NEA, its coverage is less than $25 \%$.

4. The generally accepted debt equity ratio is 70:30. 